\title{
Developing row spacing and planting density recommendations for yacon (Smallanthus sonchifolius) in tropical highland conditions
}

\author{
Arnaldo H. de O. Carvalho ${ }^{1 *}$, Joab L.F. Pedrosa ${ }^{2}$, Fábio L. de Oliveira ${ }^{2}$, Magno do C. Parajara ${ }^{3}$, \\ Leonardo J.F.N. da Rocha ${ }^{4}$, Wallace L. de Lima ${ }^{5}$, and Ariany das G. Teixeira ${ }^{6}$
}

\begin{abstract}
'Instituto Federal de Educação, Ciência e Tecnologia do Espírito Santo, Ibatiba 29395-000, Espírito Santo, Brasil.
*Corresponding author (acarvalho@ifes.edu.br).

${ }^{2}$ Universidade Federal do Espírito Santo, Departamento de Agronomia, Alegre 29500-000, Espírito Santo, Brasil.

${ }^{3}$ Universidade Federal de Viçosa, Departamento de Fitotecnia, Viçosa 36570-900, MG, Brasil.

${ }^{4}$ Southern Illinois University, Department of Plant, Soil \& Agricultural Systems, Carbondale, IL 62901, Illinois, USA.

${ }^{5}$ Instituto Federal do Espirito Santo, Programa de Pós-graduação em Agroecologia, Alegre 29520-000, Espírito Santo, Brasil.

${ }^{6}$ Instituto Federal do Espirito Santo, Departamento de Agronomia, Santa Teresa 29660-000, Espírito Santo, Brasil.
\end{abstract}

Received: 22 September 2020; Accepted: 26 December 2020; doi:10.4067/S0718-58392021000200237

\begin{abstract}
Yacon (Smallanthus sonchifolius [Poepp.] H. Rob.,Asteraceae) is an Andean plant being explored as a functional food, due to high concentrations of fructooligosaccharides (FOS), a natural sweetener capable of reducing blood lipids and glucose levels, supporting prevention of chronic diseases, such as diabetes. Yacon commercial production is still being established, thus cropping practices and their impact on profitability are yet poorly explained. Improved planting recommendations are demanded, as it affects crop yield. In this background, a field trial was conducted to determine row spacing and plant populations for yacon production in tropical highland areas. The experimental design was a randomized complete block, in a split-plot scheme, where blocks were three row spacings $(0.8,1.0$ and $1.2 \mathrm{~m})$ and subplots covered three spacings between plants $(0.4,0.5$ and $0.6 \mathrm{~m})$, with four replicates. At harvest time, evaluations on accumulation of dry mass in the plant and tuber root production data (number, weight, total productivity, and per class) were made. Profitability indicators were estimated (gross income, operational profit, and benefit-cost ratio). Data suggest productive and economic variations among tested planting configurations, as an example higher productivity $\left(31.5 \mathrm{tha}^{-1}\right)$ and positive benefit-cost ratio (2.51) when using $1.0 \mathrm{~m}$ between rows and $0.4 \mathrm{~m}$ between plants for the conditions tested. These results point out the prospect to select better crop management practices for yacon, cutting costs, and increasing yield. Another key find was yacon's capacity to overcome intense drought and temperature stress, not previously documented for this crop. Therefore, yacon is a new crop with potential to boost farming income through crop diversification.
\end{abstract}

Key words: Planting population, plant density, profitability, Smallanthus sonchifolius.

\section{INTRODUCTION}

Yacon (Smallanthus sonchifolius [Poepp.] H. Rob.) is a crop originated in the Andes, grown in elevations from 1000 to $3200 \mathrm{~m}$ a.s.l. This plant is principally noted to be rich in fructooligosaccharides (FOS), a dietary fiber that carries several nutritional aids. Yacon is recognized as a functional food, due to its antioxidant properties and the capability to support reducing blood lipid and glucose levels, which can cut down the risk of chronic diseases (Martinez-Oliveira et al., 2018; Lancetti et al., 2020). 
The expanded interest for yacon urges for management practices that can enhance crop production systems (Pedrosa et al., 2020). Adopting planting configurations promoting optimal plant populations will enhance the fit between the availability of environmental resources and the requirements of a crop, directly reflecting on yield and, thus, on crop profitability (Pereira and Hall, 2019).

By adjusting row and plant spacing, an ideal planting population can be established, which affects initial development, canopy architecture, and yield of several crops, including yacon (Mota-Júnior et al., 2014; Torales et al., 2015; Li et al., 2020). Row and plant spacing determine the spatial distribution of roots and the ability of a crop to incorporate water and nutrients from the soil (Patanè et al., 2020).

Planting configuration can as well influence the plant's response to light, as increased planting may improve light interception capacity, which would reflect an increased photosynthetic capacity (Li et al., 2020). A lower density of plants can reduce light absorption rates, reducing yield potential ( $\mathrm{Li}$ et al., 2020). However, planting arrangement and density may likewise stimulate competition between plants for resources (water, light, nutrients), leading to morphological modifications (vegetative and reproductive) in plants, due to canopy adaptation to these conditions, which may as well decrease yield.

Therefore, optimal planting configuration and density is fundamental information to support optimal use of environmental resources, maximizing yield, and profitability of a crop. For yacon, another circumstance to acknowledge is that this crop is yet being fit to growing conditions outside the Andes and is responding differently to environmental conditions in new growing zones. Environmental conditions will change, for example, the time demanded to achieve physiological maturity, which can range from 6- to 10-mo after planting, affecting yield potential (Silva et al., 2019). These responses even vary due to seasonal climatic patterns Silva et al. (2018a), showing that crop response to management practices must be verified under different environments. Therefore, the purpose of this research project was to assess yacon planting spacing and configuration in tropical highland conditions.

\section{MATERIALS AND METHODS}

Field trials were conducted in a small farming community, situated in the mountains of Alto Norte village, municipality of Muniz Freire (20 $0^{\circ} 4^{\prime} \mathrm{S}, 41^{\circ} 24^{\prime \prime}$ W; 1146 m a.s.l.), State of Espírito Santo, Brazil. This zone is characterized by a mountainous environment, with moderate temperatures and rainfall over the state's average (Pezzopane et al., 2012). Average monthly temperatures fluctuated from 17 to $26^{\circ} \mathrm{C}$, and rainfall summed $1296 \mathrm{~mm}$ during field experiments, based on statistics from the National Meteorological Institute of Brazil (INMET). The region experienced an extreme drought during trials, with low precipitations in May 2016, limiting even the availability of irrigation water. Besides, unusually low temperatures $\left(3^{\circ} \mathrm{C}\right)$ were registered, even with a record of light frosts in some fields (Figure 1).

Figure 1. Monthly rainfall and average, maximum and minimum temperatures recorded from March 2016 to February 2017, in Muniz Freire, Espírito Santo, Brazil.

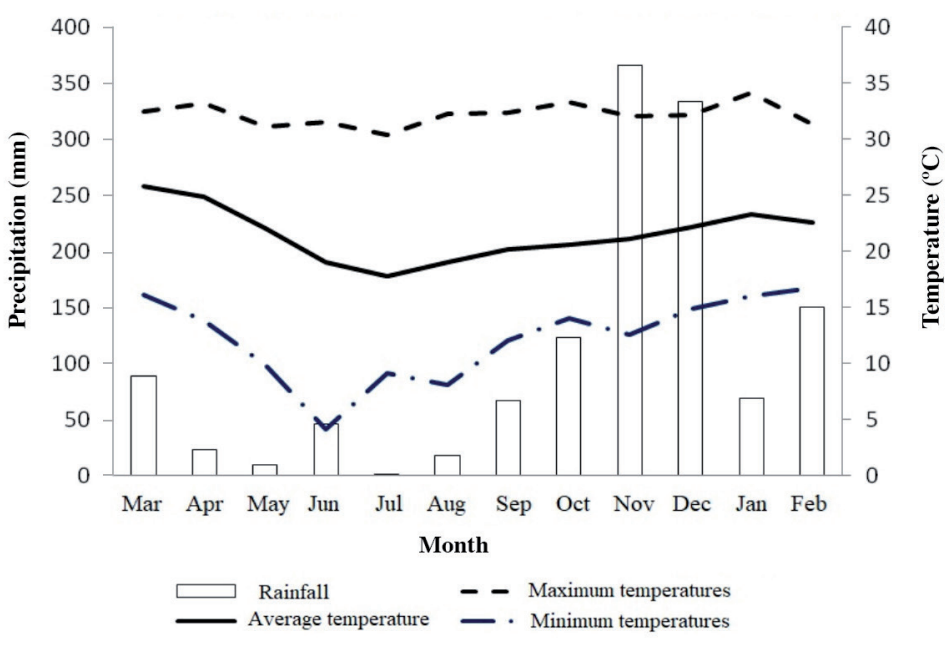

Source: INMET Meteorological Information System, 2017. 
The soil around the experimental plot was classified as a red-yellow Oxysol, medium texture (Embrapa, 2014). Soil samples were collected in the $0-20 \mathrm{~cm}$ layer and analysis returned the following results: $\mathrm{pH}\left(\mathrm{H}_{2} \mathrm{O}\right) 5.9 ; 39.80 \mathrm{mg} \mathrm{P} \mathrm{dm}^{-3}$ (P-Mehlich); $69 \mathrm{mg} \mathrm{K} \mathrm{dm}{ }^{-3} ; 0.0 \mathrm{cmol}_{\mathrm{c}} \mathrm{Al} \mathrm{dm}{ }^{-3} ; \mathrm{H}+\mathrm{Al}: 1.80 \mathrm{cmol}_{\mathrm{c}} \mathrm{dm}^{-3} ; 1.35 \mathrm{cmol}_{\mathrm{c}} \mathrm{Ca} \mathrm{dm}^{-3} ; 0.49 \mathrm{cmol}_{\mathrm{c}} \mathrm{Mg} \mathrm{dm}^{-3} ;$ total bases (SB) $1.97 \mathrm{cmol}_{\mathrm{c}} \mathrm{dm}^{-3}$; base saturation $52.25 \%$; cation exchange capacity (CEC) 3.77 ; organic matter (OM) $14 \mathrm{~g} \mathrm{~kg}^{-1}$ (1.4\%). The field was tilled and disked prior to planting.

Yacon (Smallanthus sonchifolius [Poepp.] H. Rob.) was planted in March 2016, in planting pits measuring $15 \mathrm{~cm} \times 15 \mathrm{~cm}$ (depth $\times$ diameter). Seedlings had three pairs of leaves, $10 \mathrm{~cm}$ in height, and were produced in plastic bags $(10 \times 18 \mathrm{~cm})$ filled with 2:1 soil and bovine manure mixture. The seedlings were produced from rhizophores collected from plants with the same genotype (Lorenzoni et al., 2017).

Organic fertilization comprised cow manure in doses of $180 \mathrm{~g}$ per plant. Manure analysis resulted in: $15.05 \mathrm{~g} \mathrm{~N} \mathrm{~kg}^{-1}$; $6.00 \mathrm{~g} \mathrm{P} \mathrm{kg}^{-1} ; 30.07 \mathrm{~g} \mathrm{~K} \mathrm{~kg}^{-1} ; 9.10 \mathrm{~g} \mathrm{Ca} \mathrm{kg}^{-1}$ and $8.75 \mathrm{~g} \mathrm{Mg} \mathrm{kg}^{-1}\left(1 \mathrm{~g} \mathrm{~kg}^{-1}=1 \%\right)$. Throughout the growing season, weeds were removed, and irrigation was conducted via a conventional sprinkler system. However, irrigation was interrupted for 4-mo during the growing season (from 60 to $180 \mathrm{~d}$ after planting), due to supply issues in the water reservoir, which reached unusually low levels caused by the extended drought period experienced by that region.

The experimental design was a randomized complete block in split-plots. Main treatments (blocks) were three row spacings $(0.8,1.0$ and $1.2 \mathrm{~m})$ and subplots were three spacings between plants within rows $(0.4,0.5$ and $0.6 \mathrm{~m})$, with four replicates. Each experimental block comprised 4 rows with 7 plants per row, in a total of 28 plants per block. Only the 10 plants in the center of two central rows were utilized for evaluations.

Plant height $(\mathrm{cm})$ was measured through the crop cycle at 90, 120, 150, 180, 210, 240, 270, and $300 \mathrm{~d}$ after planting (DAP). The cropping cycle ended at 300 DAP, marked by the beginning of flowering and plant senescence. Crop yield and quality parameters were evaluated at 300 DAP. For crop yield, average number, weight, diameter, and length of tuberous roots per plant were evaluated. The quality of tuberous roots was also evaluated, based on the following scale: $1 \mathrm{~A}(<130 \mathrm{~g}$; from 7 to $13 \mathrm{~cm}$ in length); $2 \mathrm{~A}$ (between 130 and $250 \mathrm{~g} ; 13$ to $18 \mathrm{~cm}$ in length), and $3 \mathrm{~A}$ ( $>250 \mathrm{~g} ;>18 \mathrm{~cm}$ in length), following the method proposed by Oliveira (2016).

Based on yield data, an economic analysis was conducted for each spatial arrangement. Data and information on prices were gathered from the Espírito Santo State Vegetable Distribution Center (CEASA-ES), while technical coefficients and production costs were produced by dialoguing with local growers. The method used to calculate production costs and test indicators and profitability results was based on the work by Furlaneto and Esperancini (2010).

Production cost data included effective operating cost (EOC), which covers expenses with labor, operations of machinery/equipment and inputs used throughout the cultivation cycle (fertilizers, irrigation), and the total operating cost (TOC). In this survey, TOC includes social security contributions (2.3\% gross income).

The profitability analysis indicators were gross income (GI), profit margin (PM) and cost/profit ratio (CPR). Gross income (GI): expected revenue for a given production per hectare, $\mathrm{GI}=\mathrm{Pr} \times \mathrm{Pu}$, where $\mathrm{Pr}$ is yacon production per area $\left(\mathrm{kg} \mathrm{ha}^{-1}\right)$ and $\mathrm{Pu}$ is price per unit of yacon $(1 \mathrm{~kg})\left(\mathrm{USD} \mathrm{kg}^{-1}\right)$; calculations were based on a base price of Brazilian reals (BRL) $1.75 \mathrm{~kg}^{-1}$ (average values traded between January and February 2020, at the Espírito Santo State Vegetable Distribution Center, CEASA-ES), translated to dollars, based on the BRL-USD exchange rate BRL 4.63 = USD 1.00 on 3 June 2020. Profit margin (PM): difference between GI and total operating cost (TOC) per hectare; PM = GI - TOC. Cost/ Profit ratio $(\mathrm{CPR})=\mathrm{GI} / \mathrm{TOC}$.

To determine production costs, the average values from farmers were used when estimating the value of each rhizophore, resulting in an average of USD 0.05 (five cents) per unit of $50 \mathrm{~g}$ (value based on BRL-USD dollar exchange rate in 3 June 2020). Labor production cost was predicted based on the equivalent of 27 workdays (WD) per hectare, with 20000 plant population, in an arrangement of $0.8 \times 0.5 \mathrm{~m}$, based in data compiled from farmers. The cost of organic fertilizer was determined based on the work of Garcia and Souza (2015). For each population planting configuration, costs were estimated and are displayed in Table 1.

Data were subjected to ANOVA and, after factorial interaction was detected, the sub-plots were split within each plot. Plant height data were submitted to regression analysis, and the linear equation was adjusted to the $2^{\text {nd }}$-degree polynomial model. The other treatment averages, when significant by the F test, were contrasted using the Tukey test $\operatorname{HSD}(\mathrm{p}<0.05)$. 
Table 1. Estimated production costs per hectare of yacon produced under different planting arrangements, in tropical highland conditions.

\begin{tabular}{|c|c|c|c|c|c|c|c|c|}
\hline \multirow[b]{2}{*}{ Item } & \multirow[b]{2}{*}{ Unit } & \multirow{2}{*}{$\begin{array}{l}{\text { Unit } \cos t^{1}} \\
\text { USD }\end{array}$} & \multicolumn{2}{|c|}{$0.8 \times 0.4 \mathrm{~m}$} & \multicolumn{2}{|c|}{$0.8 \times 0.5 \mathrm{~m}$} & \multicolumn{2}{|c|}{$0.8 \times 0.6 \mathrm{~m}$} \\
\hline & & & Unit & Total & Unit & Total & Unit & Total \\
\hline \multicolumn{9}{|l|}{ 1-Inputs } \\
\hline Cow manure & $\mathrm{t}$ & 17.50 & 15 & 262.50 & 15 & 262.50 & 15 & 262.50 \\
\hline Seedlings & unit & 0.05 & 31250 & 1562.50 & 25000 & 1250.00 & 20833 & 1041.65 \\
\hline \multicolumn{9}{|l|}{ 2-Services } \\
\hline Tilling/disking & $\mathrm{H} / \mathrm{T}$ & 15.00 & 6 & 90.00 & 6 & 90.0 & 6 & 90.00 \\
\hline Planting & $\mathrm{D} / \mathrm{H}$ & 12.50 & 42 & 525.00 & 34 & 425.00 & 28 & 350.00 \\
\hline Weed control & $\mathrm{D} / \mathrm{H}$ & 12.50 & 34 & 425.00 & 28 & 350.00 & 23 & 287.50 \\
\hline Fertilizers & $\mathrm{D} / \mathrm{H}$ & 12.50 & 47 & 587.50 & 38 & 475.00 & 31 & 387.50 \\
\hline Harvest & $\mathrm{D} / \mathrm{H}$ & 12.50 & 42 & 525.00 & 34 & 425.00 & 28 & 350.00 \\
\hline Classification & $\mathrm{D} / \mathrm{H}$ & 12.50 & 42 & 525.00 & 34 & 425.00 & 28 & 350.00 \\
\hline Irrigation & $\mathrm{D} / \mathrm{H}$ & 12.50 & 10 & 125.00 & 10 & 125.00 & 10 & 125.00 \\
\hline EOC & & & & 4627.50 & & 3827.50 & & 3244.15 \\
\hline \multicolumn{9}{|c|}{ 3-Additional costs } \\
\hline Taxes & & \multicolumn{2}{|c|}{$2.3 \% \mathrm{GI}$} & 167.6 & & 186.30 & & 127.42 \\
\hline \multirow[t]{2}{*}{ TOC } & & & & 4795.17 & & 4013.80 & & 3371.57 \\
\hline & & Unit cost ${ }^{1}$ & \multicolumn{2}{|c|}{$1.0 \times 0.4 \mathrm{~m}$} & \multicolumn{2}{|c|}{$1.0 \times 0.5 \mathrm{~m}$} & \multicolumn{2}{|c|}{$1.0 \times 0.6 \mathrm{~m}$} \\
\hline Item & Unit & USD & Unit & Total & Unit & Total & Unit & Total \\
\hline \multicolumn{9}{|l|}{ 1-Inputs } \\
\hline Cow manure & $\mathrm{t}$ & 17.50 & 15 & 262.50 & 15 & 262.50 & 15 & 262.50 \\
\hline Seedlings & unit & 0.05 & 25000 & 1250.00 & 20000 & 1000.00 & 16667 & 833.35 \\
\hline \multicolumn{9}{|l|}{ 2-Services } \\
\hline Tilling/disking & $\mathrm{H} / \mathrm{T}$ & 15.00 & 6 & 90.00 & 6 & 90.00 & 6 & 90.00 \\
\hline Planting & $\mathrm{D} / \mathrm{H}$ & 12.50 & 34 & 425.00 & 27 & 337.50 & 23 & 287.50 \\
\hline Weed control & $\mathrm{D} / \mathrm{H}$ & 12.50 & 28 & 350.00 & 22 & 275.00 & 18 & 225.00 \\
\hline Fertilizers & $\mathrm{D} / \mathrm{H}$ & 12.50 & 38 & 475.00 & 30 & 375.00 & 25 & 312.50 \\
\hline Harvest & $\mathrm{D} / \mathrm{H}$ & 12.50 & 34 & 425.00 & 27 & 337.50 & 23 & 287.50 \\
\hline Classification & $\mathrm{D} / \mathrm{H}$ & 12.50 & 34 & 425.00 & 27 & 337.50 & 23 & 287.50 \\
\hline Irrigation & $\mathrm{D} / \mathrm{H}$ & 12.50 & 10 & 125.00 & 10 & 125.00 & 10 & 125.00 \\
\hline EOC & & & & 3827.50 & & 3140.00 & & 2710.85 \\
\hline \multicolumn{9}{|c|}{ 3-Additional costs } \\
\hline Taxes & & \multicolumn{2}{|c|}{$2.3 \% \mathrm{GI}$} & 234.74 & & 178.81 & & 161.70 \\
\hline \multirow[t]{2}{*}{ TOC } & & & & 4062.24 & & 3318.84 & & 2872.55 \\
\hline & & & & $4 \mathrm{~m}$ & & $5 \mathrm{~m}$ & & $6 \mathrm{~m}$ \\
\hline Item & Unit & USD & Unit & Total & Unit & Total & Unit & Total \\
\hline 1-Inputs & & & & & & & & \\
\hline Cow manure & $\mathrm{t}$ & 17.50 & 15 & 262.50 & 15 & 262.50 & 15 & 262.50 \\
\hline Seedlings & unit & 0.05 & 20833 & 1041.65 & 16667 & 833.35 & 13889 & 694.45 \\
\hline 2-Services & & & & & & & & \\
\hline Tilling/disking & $\mathrm{H} / \mathrm{T}$ & 15.00 & 6 & 90.00 & 6 & 90.00 & 6 & 90.00 \\
\hline Planting & $\mathrm{D} / \mathrm{H}$ & 12.50 & 28 & 350.00 & 23 & 287.50 & 19 & 237.50 \\
\hline Weed control & $\mathrm{D} / \mathrm{H}$ & 12.50 & 23 & 287.50 & 18 & 225.00 & 15 & 187.50 \\
\hline Fertilizers & $\mathrm{D} / \mathrm{H}$ & 12.50 & 31 & 387.50 & 25 & 312.50 & 21 & 262.50 \\
\hline Harvest & $\mathrm{D} / \mathrm{H}$ & 12.50 & 28 & 350.00 & 23 & 287.50 & 19 & 237.50 \\
\hline Classification & $\mathrm{D} / \mathrm{H}$ & 12.50 & 28 & 350.00 & 23 & 287.50 & 19 & 237.50 \\
\hline Irrigation & $\mathrm{D} / \mathrm{H}$ & 12.50 & 10 & 125.00 & 10 & 125.00 & 10 & 125.00 \\
\hline EOC & & & & 3244.15 & & 271.85 & & 2334.45 \\
\hline 3-Additional co & & & & & & & & \\
\hline Taxes & & & & 184.81 & & 178.10 & & 84.20 \\
\hline TOC & & & & 3428.96 & & 2888.94 & & 2418.65 \\
\hline
\end{tabular}

'Values based in the exchange ratios from Brazilian real to USD (BRL 4.63: USD 1.00 in 3 June 2020).

EOC: Effective operational cost; TOC: total operational cost; H/T: tractor hours, unit to calculate machine usage cost, machine hour cost; D/H: man-days, unit to calculate how many days a worker performs that activity; GI: gross income. 


\section{RESULTS}

ANOVA revealed significant factorial interaction among spacing between rows and plants and, thus, subplots (spacing between plants within the row) were studied separately within each plot (row spacing).

Data showed a decline in plant height at the beginning of the crop cycle, across treatments, reaching even a total lack of shoots from 120 to 180 DAP (Figure 2). After 210 DAP, plants started growing vigorously again, notably in plots planted in row spacings of 0.8 and $1.0 \mathrm{~m}$, and between plant spacings of $0.5 \mathrm{~m}$ through the end of crop season (240-300 DAP) (Figures 2A and 2B). However, in $1.2 \mathrm{~m}$ row spacing, peak heights were observed in $0.4 \mathrm{~m}$ between plants (Figure 2C).

For the yacon yield of tuberous roots, stronger values were taken for between plant spacings of 0.4 and $0.5 \mathrm{~m}$ when $0.8 \mathrm{~m}$ row were used. Comparable results were noticed for $1.2 \mathrm{~m}$ rows. With $1.0 \mathrm{~m}$ row spacing, the highest yields were observed with $0.4 \mathrm{~m}$ between plants (Table 2).

When analyzing yield by the quality of tuberous roots, $0.8 \mathrm{~m}$ row spacing led to a further yield of class $1 \mathrm{~A}$ roots, in between plant spacing of $0.4 \mathrm{~m}$. Row spacing of $1.0 \mathrm{~m}$ presented analogous results. For 1.2 between rows, the highest $1 \mathrm{~A}$ yields were detected when using $0.5 \mathrm{~m}$ between plants (Table 2 ).

Figure 2. Height of yacon plants under different planting arrangements, in tropical highland conditions. Row spacings of $0.8(\mathrm{~A}), 1.0(\mathrm{~B})$ and $1.2 \mathrm{~m}(\mathrm{C})$, with respective spacings between plants $(0.4,0.5$ and $0.6 \mathrm{~m})$.
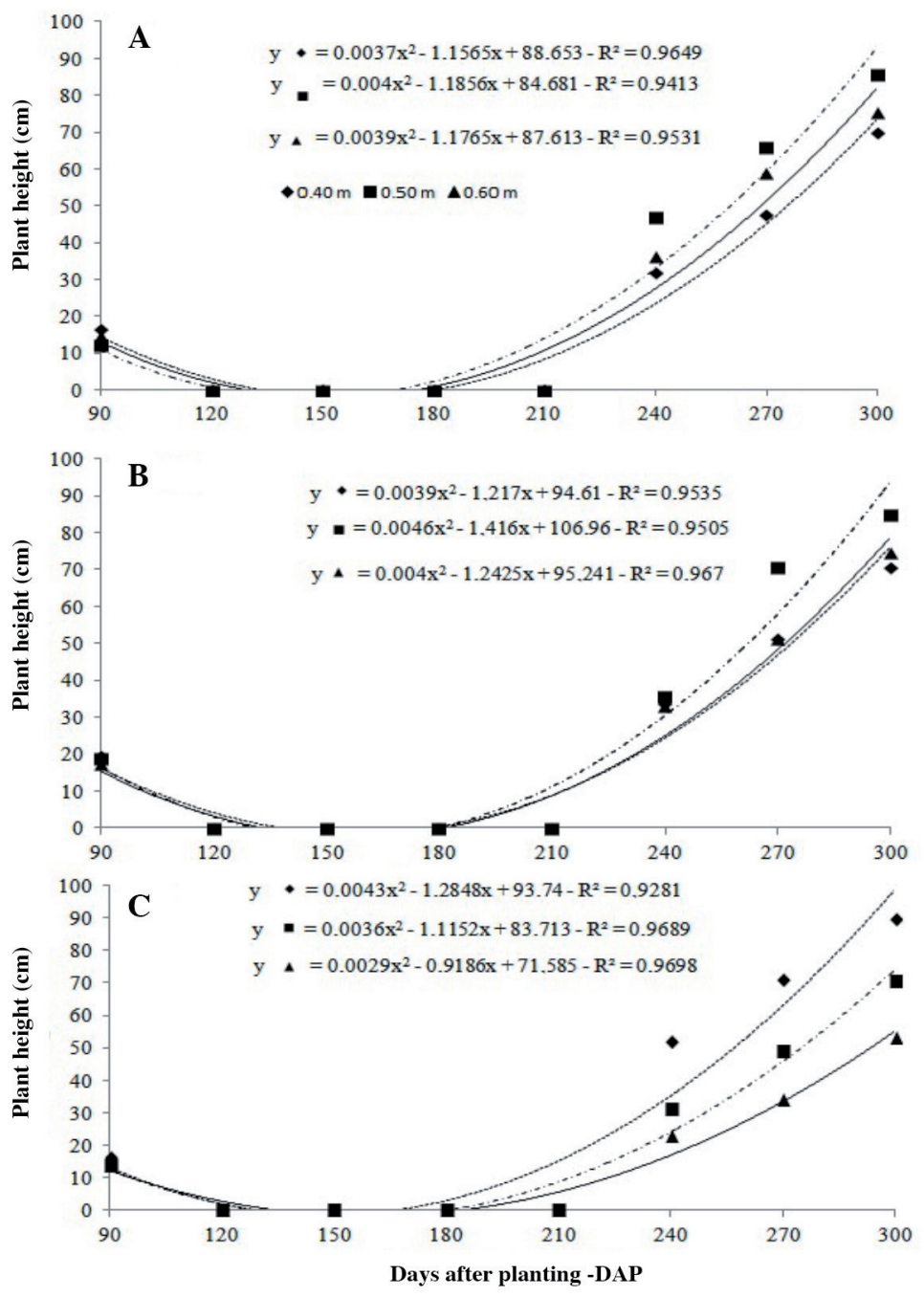
Higher yields of $2 \mathrm{~A}$ roots for $0.8 \mathrm{~m}$ between rows were noted when using $0.5 \mathrm{~m}$ between plants. No classification differences were observed due to between plant spacing when using $1.0 \mathrm{~m}$ between rows. For 1.2 between rows, a greater 2A yield was produced using 0.4 and $0.5 \mathrm{~m}$ between plants (Table 2).

Regarding the profitability of planting configuration, larger gross income (GI) and profit margins (PM) were compiled using a row spacing of $1.0 \mathrm{~m}$ and $0.4 \mathrm{~m}$ between plants (USD 10206.00-6143.76). However, this planting configuration showed the second-best CPR (2.51), marginally smaller compared to values (2.68) obtained from the $1.2 \times 0.5$ arrangement (Table 3). Although $1.0 \times 0.4 \mathrm{~m}$ produced the second-best RBC (2.51) and greatest yield ( $\left.31.5 \mathrm{t} \mathrm{ha}^{-1}\right)$, this arrangement led to the second-largest production cost in comparison to others.

Table 2. Yield of yacon tuberous roots in total values and separated by classes, produced under different planting arrangements, in tropical highland conditions.

\begin{tabular}{|c|c|c|c|c|c|c|}
\hline \multirow[b]{4}{*}{ Spacing between plants $(\mathrm{m})$} & \multicolumn{6}{|c|}{ Row spacing $(\mathrm{m})$} \\
\hline & 0.8 & 1.0 & 1.2 & 0.8 & 1.0 & 1.2 \\
\hline & \multicolumn{6}{|c|}{ Yield of tuberous roots $\left(\mathrm{t} \mathrm{ha}^{-1}\right)$} \\
\hline & \multicolumn{3}{|c|}{ Total } & \multicolumn{3}{|c|}{ Class 1A } \\
\hline 0.4 & $22.5 \mathrm{a}$ & $31.5 \mathrm{a}$ & $24.8 \mathrm{a}$ & $4.9 \mathrm{a}$ & $10.7 \mathrm{a}$ & $7.3 \mathrm{~b}$ \\
\hline 0.5 & $25.0 \mathrm{a}$ & $24.0 \mathrm{~b}$ & $23.9 \mathrm{a}$ & $3.3 b$ & $7.7 \mathrm{~b}$ & $8.9 a$ \\
\hline 0.6 & $17.1 \mathrm{~b}$ & $21.7 b$ & $11.3 \mathrm{~b}$ & $2.9 \mathrm{~b}$ & $5.9 \mathrm{c}$ & $0.0 \mathrm{c}$ \\
\hline \multirow[t]{2}{*}{$\mathrm{CV}$} & & $12.25 \%$ & & & $8.49 \%$ & \\
\hline & \multicolumn{3}{|c|}{ Class 2A } & \multicolumn{3}{|c|}{ Class 3A } \\
\hline 0.4 & $4.8 b$ & $6.0 \mathrm{a}$ & $5.9 \mathrm{a}$ & $12.8 \mathrm{a}$ & $14.9 \mathrm{a}$ & $11.6 \mathrm{a}$ \\
\hline 0.5 & $8.7 \mathrm{a}$ & $6.6 \mathrm{a}$ & $5.5 \mathrm{a}$ & $12.9 \mathrm{a}$ & $9.7 \mathrm{~b}$ & $9.6 \mathrm{a}$ \\
\hline 0.6 & $3.3 b$ & $5.7 \mathrm{a}$ & $3.1 \mathrm{~b}$ & $10.9 \mathrm{~b}$ & $10.1 \mathrm{~b}$ & $8.2 \mathrm{~b}$ \\
\hline $\mathrm{CV}$ & & $15.06 \%$ & & & $7.33 \%$ & \\
\hline
\end{tabular}

Values followed by the same letter in the columns do not differ using the Tukey test HSD ( $<<0.05)$.

$\mathrm{CV}$ : Coefficient of variation.

Table 3. Yield, gross income, production cost, profit and benefit-cost ratio of commercial yacon roots produced in different planting arrangements, in tropical highland conditions.

\begin{tabular}{|c|c|c|c|c|c|c|}
\hline Arrangement & Population & Yield & Gross income ${ }^{1}$ & Costs $^{2}$ & Profit & $\begin{array}{l}\text { Cost/Profit } \\
\text { ratio (CPR) }\end{array}$ \\
\hline $\mathrm{m}$ & plants $\mathrm{ha}^{-1}$ & $\mathrm{t} \mathrm{ha}^{-1}$ & $S_{2}$ & USD - & - & \\
\hline $0.8 \times 0.4$ & 31250 & 22.5 & 7290.00 & 4795.17 & 2494.83 & 1.52 \\
\hline $0.8 \times 0.5$ & 25000 & 25.0 & 8100.00 & 4013.78 & 4086.22 & 2.01 \\
\hline $0.8 \times 0.6$ & 20833 & 17.1 & 5540.04 & 3371.57 & 2168.47 & 1.64 \\
\hline $1.0 \times 0.4$ & 25000 & 31.5 & 10206.00 & 4062.24 & 6143.76 & 2.51 \\
\hline $1.0 \times 0.5$ & 20000 & 24.0 & 7776.00 & 3318.83 & 4457.16 & 2.34 \\
\hline $1.0 \times 0.6$ & 16666 & 21.7 & 7030.80 & 2872.55 & 4158.25 & 2.45 \\
\hline $1.2 \times 0.4$ & 20833 & 24.8 & 8035.20 & 3428.94 & 4606.24 & 2.34 \\
\hline $1.2 \times 0.5$ & 16666 & 23.9 & 7743.60 & 2888.94 & 4854.66 & 2.68 \\
\hline $1.2 \times 0.6$ & 13888 & 11.3 & 3661.20 & 2418.65 & 1242.55 & 1.51 \\
\hline
\end{tabular}

${ }^{1}$ BRL $1.50 \mathrm{~kg}^{-1}$, price paid for producers at Espírito Santo State Vegetable Distribution Center (CEASA-ES), on 3 June 2020

${ }^{2}$ Yacon production cost per hectare (refer to Table 1).

Values based on BRL-USD dollar exchange rate in 3 June 2020 (BRL 4.63: USD 1.00). 


\section{DISCUSSION}

Yacon's initial growth and development is irregular, which is prevalent in plants propagated vegetatively, achieving uniform growth only after 90 DAP (Silva et al., 2019). Because of these circumstances, plant ratings started at 90 DAP. However, at this time, plants started to reduce the volume of shoots and leaves (Figure 2), due to drought stress encountered by that region in April and May (2016), with only 20 and $10 \mathrm{~mm}$ of rainfall for each month, respectively.

Associated with extreme drought, for the region where field trials were conducted, historically low temperatures were reported, registering an absolute minimum of $3{ }^{\circ} \mathrm{C}$ and frosting in some areas. For yacon, low temperatures and the lack of soil moisture, are major factors governing the development of tuberous roots (Kamp et al., 2019a). These two factors in the association were major limitations of crop growth, branching, and initial development of tuberous roots (Silva et al., 2019).

However, the crop recovered even after losing all leaves, which was a case not reported yet and demonstrate the resilience of yacon. Under these conditions, plants can initiate a dormancy stage, a defense strategy prevalent in plants from low-temperature regions, as the Andes (Tokita et al., 2015). With yacon, plants reallocate reserves compounds from shoots to the rhizophores, the underground stem structure used by the plant to accumulate carbohydrates. Rhizophores have many gems and thus the main source of yacon propagation (Pedrosa et al., 2020).

Following later precipitations associated with surges in temperature, plants resumed dormancy and started growing again. Temperatures over $10{ }^{\circ} \mathrm{C}$ stimulated plant growth, boosting rhizophore germination rates and contributing to a rapid recovery of shoots and leaves, as noted for other tuberous roots (Carillo et al., 2019).

Total yield was influenced by the various planting configurations and overall, best yields were reached using smaller spacings between plants $(0.4$ and $0.50 \mathrm{~m})$, for all tested row spacings.

Comparable results were documented by Tokita et al. (2015), whose results illustrated that increased plant populations led to a decline in production of each plant, but the yield was compensated due to larger plant populations. These authors reported yields of $18.9 \mathrm{t} \mathrm{ha}^{-1}$, with an average of $1517 \mathrm{~g}$ roots per plant, when managed in $1.0 \mathrm{~m}$ between rows and $0.8 \mathrm{~m}$ between plants. Yields of $22.2 \mathrm{tha}^{-1}$ and an average of $1064 \mathrm{~g}$ roots per plant were registered using $0.8 \mathrm{~m}$ between rows and $0.6 \mathrm{~m}$ between plants.

The results from this trial and the literature highlight that planting recommendations influences yacon yield, due to its direct impact on yacon's use of resources such as water, light, and nutrients (Kappes et al., 2011). However, diverse factors may as well promote variations in the response to each unique condition to cultivation, as variations in these conditions can promote intraspecific competition, prompted by larger plant populations, and so reduce yacon yield (Kamp et al., 2019b).

The yield of yacon tuberous root in the present study was lower when compared to other studies in the same region, Silva et al. (2018a; 2019), 40 and $77 \mathrm{t} \mathrm{ha}^{-1}$ respectively. This reduction in yield can be linked to a shorter period for accumulation of reserve compounds, as crop growth was restricted by drought and lower temperatures, with suitable conditions only after 180 DAP, and harvested conducted at 300 DAP.

The crop experience only about $120 \mathrm{~d}$ of favorable conditions before harvest. Based on the results of Silva et al. (2018b), in the present region, optimal crop growth and root development occurred from 120 to $180 \mathrm{~d}$ of the cycle. Kamp et al. (2019a) likewise emphasize that yacon needs about $200 \mathrm{~d}$ under satisfactory conditions to achieve optimal yields. The lack of optimal conditions is noticeable since regardless of planting configurations, a considerable part of roots, close to $50 \%$, were classified in smaller size groups (classes $1 \mathrm{~A}$ and $2 \mathrm{~A}-<250 \mathrm{~g}$ ), showing that these roots were not entirely developed. However, the greatest number of roots produced was classified as class $3 \mathrm{~A}$, roots with the highest market value (Oliveira, 2016).

On the influence of spacing on root classification, results followed similar like trends noted for yield, with smaller spacings between plants $(0.4$ and sometimes $0.5 \mathrm{~m})$ being more favorable within each category. This demonstrates that the proportion between root categories is being maintained and differences are due to yield changes.

Profitability is a variable influenced by market variations. Yacon supply was currently reduced at time of harvest, due to increased demand ("in natura" consumption recommended for diabetes treatment), contributing to the increased sale price, which affects profitability margins and change CPR values. 
If the gross income increases but production costs are preserved unaltered, planting recommendations with higher yields will be more profitable. In the present trial, planting arrangements of $1.0 \times 0.4$ led to the highest yield and second highest CPR, close to the best (2.68) obtained with the $1.2 \times 0.5$ arrangement. The higher CPR obtained with $1.2 \times 0.5$ may be linked to lower costs with propagating material and cheapest production cost (USD 2888.94), which yielded better profits compared to investments, despite lower yields.

These results show that detailed economic analysis is essential to understand how farming production activities can be exaggerated to boost profits (Heid et al., 2019). Besides, research with other root and tuberous crops, such as Jerusalem artichoke, suggests a demand to commercialize several parts of the plant to make a farming operation profitable (Johansson et al., 2015).

Alternatives such as the commercialization of secondary plant structures, such as rhizophores and leaves, must be considered to add value to the crop. Rhizophores, for example, represent a considerable part of the production costs. Farmers selling rhizophores as propagative material would gain extra revenue at harvest. Alternatively, producers could use rhizophores as a propagative material for a second field, cutting costs when acquiring propagating material, enhancing production balances, either by cutting down costs or raising revenue.

Yacon leaves, which commercial value was not given in this study, can be commercialized if a market is accessible. They are used for teas shown to help manage diabetes and can reduce bad cholesterol (Cruz et al., 20019). These leaves may as well have topical anti-inflammatory activity, which may be utilized by the pharmaceutical industry (Johansson et al., 2015).

\section{CONCLUSIONS}

The most suitable planting arrangement for yacon in highland tropical conditions is using $1.0 \mathrm{~m}$ between rows and $0.4 \mathrm{~m}$ between plants. This configuration produced higher yield, gross income, and profit, and must be endorsed under conditions for those conditions, even though the best cost-benefit ratio was not found under this arrangement.

Another key finding was the ability of yacon to recover after drought and temperature stress, not yet reported for this crop. This denotes a considerable adaptive response of the plant, indicating the suitability of yacon production and profitability under these conditions. These results can help farmers by providing planting instructions for yacon in tropical highland conditions and increasing farm income through crop diversification.

\section{ACKNOWLEDGEMENTS}

The authors are grateful to the Espírito Santo Research Support Foundation (FAPES, Vitória-ES, Brazil), to the National Council for Scientific and Technological Development (CNPq, Brasília-DF, Brazil), to the Instituto Federal do Espírito Santo for the financial contribution and Coordination for the Improvement of Higher Education Personnel (CAPES, Brasília-DF, Brazil), for their financial assistance via grants and scholarships.

\section{REFERENCES}

Carillo, P., Arena, C., Modarelli, G.C., De Pascale, S., and Paradiso, R. 2019. Photosynthesis in Ranunculus asiaticus L.: the influence of the hybrid and the preparation procedure of tuberous roots. Frontiers in Plant Science 10:241. doi:10.3389/fpls.2019.00241

Cruz, P.N., Fetzer, D.L., do Amaral, W., de Andrade, E.F., Corazza, M.L., and Masson, M.L. 2019. Antioxidant activity and fatty acid profile of yacon leaves extracts obtained by supercritical $\mathrm{CO}_{2}+$ ethanol solvent. The Journal of Supercritical Fluids 146:55-64. doi:10.1016/j.supflu.2019.01.007.

Embrapa. 2014. Sistema brasileiro de classificação de solos. p. 367. Embrapa Solos, Rio de Janeiro, Brasil.

Furlaneto, F.D.P.B., e Esperancini, M.S.T. 2010. Custo de produção e indicadores de rentabilidade da cultura do milho safrinha. Pesquisa Agropecuária Tropical 40(3):297-303.

Garcia, R.D.C., e Souza, J.L. 2015. Desempenho econômico de cultivos orgânicos. p. 283-333. In Souza, J.L. (org.) Agricultura orgânica: tecnologias para a produção de alimentos saudáveis. Volume III. Instituto Capixaba de Pesquisa, Assistência Técnica e Extensão Rural (Incaper), Vitória, Espirito Santo, Brasil.

Heid, D.M., Zárate, N.A., Torales, E.P., Luqui, L., Moreno, L.B., Carnevali, T., et al. 2019. Seedling size and broiler litter composition affect Peruvian carrot productivity and profitability. Revista Brasileira de Ciências Agrárias 14(2):e5631. 
Johansson, E., Prade, T., Angelidaki, I., Svensson, S.E., Newson, W.R., Gunnarsson, I.B., et al. 2015. Economically viable components from Jerusalem artichoke (Helianthus tuberosus L.) in a biorefinery concept. International Journal of Molecular Sciences 16(4):8997-9016. doi:10.3390/ijms16048997.

Kamp, L., Hartung, J., Mast, B., and Graeff-Hönninger, S. 2019a. Plant growth, tuber yield formation and costs of three different propagation methods of yacon (Smallanthus sonchifolius). Industrial Crops and Products 132:1-11. doi:10.1016/j.indcrop.2019.02.006.

Kamp, L., Hartung, J., Mast, B., and Graeff-Hönninger, S. 2019b. Tuber yield formation and sugar composition of yacon genotypes grown in Central Europe. Agronomy 9(6):1-15. doi:10.3390/agronomy9060301.

Kappes, C., Andrade, J.A.D.C., Arf, O., Oliveira, A.C.D., Arf, M.V., e Ferreira, J.P. 2011. Desempenho de híbridos de milho em diferentes arranjos espaciais de plantas. Bragantia 70(2):334-343. doi:10.1590/S0006-87052011000200012.

Lancetti, R., Palavecino, P.M., Bustos, M.C., and León, A.E. 2020. Yacon (Smallanthus sonchifolius) flour obtention: Effect of process conditions on quality attributes and its incorporation in gluten-free muffins. LWT 125:109-217. doi:10.1016/j.lwt.2020.109217.

Li, X., Han, Y., Wang, G., Feng, L., Wang, Z., Yang, B., et al. 2020. Response of cotton fruit growth, intraspecific competition and yield to plant density. European Journal of Agronomy 114:1-8. doi:10.1016/j.eja.2019.125991.

Lorenzoni, R.M., Menine, F., Marques-Júnior, E.M., Oliveira, F.L., and Soares, T.C.B. 2017. Genetic diversity of yacon accessions using ISSR markers. Genetics and Molecular Research 16(2):1-8. doi:10.4238/gmr16029576.

Martinez-Oliveira, P., de Oliveira, M.F., Alves, N., Coelho, R.P., Pilar, B.C., Güllich, A.A., et al. 2018. Yacon leaf extract supplementation demonstrates neuroprotective effect against memory deficit related to $\beta$-amyloid-induced neurotoxicity. Journal of Functional Foods 48:665-675. doi:10.1016/j.jff.2018.08.004.

Mota-Júnior, C.V., Oliveira, J.M., e Mota, L.C.B.M. 2014. Avaliação da qualidade e produtividade da cenoura com diferentes densidades de plantio. Global Science and Technology 7(1):1-6.

Oliveira, T. 2016. Classificação de batata yacon. Boletim do Centro de Qualidade, Pesquisa \& Desenvolvimento da CEAGESP 1(4). Companhia de Entrepostos e Armazéns Gerais de São Paulo (CEAGESP), São Paulo, Brasil.

Patanè, C., Cosentino, S.L., Calcagno, S., Pulvirenti, L., and Siracusa, L. 2020. How do sowing time and plant density affect the pigments safflomins and carthamin in florets of safflower? Industrial Crops and Products 148:112-313. doi:10.1016/j.indcrop.2020.112313.

Pedrosa, J.L.F., de Oliveira, F.L., Zucoloto, M., Cabral, M.O., de Sales, R.A., and de Oliveira Carvalho, A.H. 2020. Yacon potato propagation from herbaceous cuttings with different numbers of buds. International Journal of Agriculture and Natural Resources 47(1):46-57. doi:10.7764/ijanr. v47i1.2134.

Pereira, M.L., and Hall, A.J. 2019. Sunflower oil yield responses to plant population and row spacing: Vegetative and reproductive plasticity. Field Crops Research 230:17-30. doi:10.1016/j.fcr.2018.09.014.

Pezzopane, J.E.M., Castro, F.S., Pezzopane, J.R.M., e Cecílio, R.A. 2012. Agrometeorologia: Aplicações para o Espírito Santo. p. 174. Caufes, Espirito Santo, Brasil.

Silva, D.M.N., Oliveira, F.L., Cavatte, P.C., Quaresma, M.A.L., and Christo, B.F. 2018a. Growth and development of yacon in different periods of planting and growing regions. Acta Scientiarum Agronomy 40(1):1-9. doi:10.4025/actasciagron.v40i1.39442.

Silva, D.M.N., de Oliveira, F.L., Quaresma, M.A.L., Erlacher, W.A., and Mendes, T.P. 2019. Yacon production at different planting seasons and growing environments. Bioscience Journal 35(4):992-1001. doi:10.14393/bj-v35n4a2019-42091.

Silva, D.M.N., Venturim, C.H.P., Capucho, M.E.O.V., de Oliveira, F.L., and Mendonça, E. 2018b. Impact of soil cover systems on soil quality and organic production of yacon. Scientia Horticulturae 235:407-412. doi:10.1016/j.scienta.2018.03.024.

Tokita, N., Ichikawa, M., Kainuma, K., Kitazawa, T., Shimamura, H., Narai-Kanayama, A., et al. 2015. Effects of planting density and fertilizer type on growth and yield of yacon (Smallanthus sonchifolius) tubers. Asian Journal of Plant Science and Research 5(11):38-41.

Torales, E.P., Zárate, N.A.H., Vieira, M., Heid, D.M., Moreno, L.B., e Grando, V.R. 2015. Produtividade da mandioquinha-salsa em resposta aos espaçamentos entre plantas e peso de mudas. Bioscience Journal 31(2):433-444. doi:10.14393/BJ-v31n2a2015-22364. 